PLANTS PEOPLE

POSSIBILITIES

\title{
A Trip to the Knysna
}

Author(s): S. Schonland

Source: Bulletin of Miscellaneous Information (Royal Botanic Gardens, Kew), Vol. 1920 , No. 7 (1920), pp. 225-231

Published by: Springer on behalf of Royal Botanic Gardens, Kew

Stable URL: http://www.jstor.org/stable/4107479

Accessed: 27-06-2016 09:37 UTC

Your use of the JSTOR archive indicates your acceptance of the Terms \& Conditions of Use, available at

http://about.jstor.org/terms

JSTOR is a not-for-profit service that helps scholars, researchers, and students discover, use, and build upon a wide range of content in a trusted digital archive. We use information technology and tools to increase productivity and facilitate new forms of scholarship. For more information about JSTOR, please contact support@jstor.org.

Royal Botanic Gardens, Kew, Springer are collaborating with JSTOR to digitize, preserve and extend access to Bulletin of Miscellaneous Information (Royal Botanic Gardens, Kew) 
ROYAL BOTANIC GARDENS, KEW.

\section{B U L L E T I N}

\section{OF MISCELLANEOUS INFORMATION.}

No. 7]

\section{XXXIII.-A TRIP TO THE KNYSNA.}

\section{S. Schonland.}

Superintendent, Albany Museum, Grahamstown, South Africa.

In connection with the work for the Botanical Survey of the Union of South Africa (started in 1918), I have used part of my holiday time in making several extensive trips with a view to planning out more detailed work and to getting some more definite information on the limits in my area of the various phytogeographical regions. Incidentally a fair number of plants were collected and observations on them noted. The last trip, which covered over 900 miles, took me from Grahamstown through the southern edge of the Great Karroo, then to the Knysna, the T'Zitzikamma, Uitenhage and back to Grahamstown. It lasted a month from the 19th of December, 1919, of which 16 days were spent at the Knysna. In making such a trip even an old resident of South Africa like myself comes across a hundred and one things of interest apart from botanical matters. The botanical results unfortunately, owing to a terrible drought, were not commensurate with the time spent in travelling. Moreover, the collections made have not been worked up yet, and when this is done they will have to be co-ordinated with the work of other botanical travellers, such as Burchell, Drège, Ecklon, Zeyher, Krauss, Schlechter, Galpin, etc., who have visited the Knysna district. I felt, therefore, some hesitation in accepting at this stage the invitation of the Director of Kew to give an account of my trip. I have, however, picked out of my diary a few items which may be of interest to readers in Europe.

Leaving Grahamstown for Somerset East grassveld is left behind within a few miles even before the descent into the Fish River valley is reached. This broad valley has quite a different climate from that of Grahamstown, and its vegetation is quite karroid. The moment we left the grassveld the effects of extreme drought became apparent. We travelled for about 300 miles up to the neighbourhood of Uniondale without seeing in the veld a single plant in flower except Acacia Karroo, and this in a region of summer rains! It is true, even at the best of times, not much rain is expected, but, for

(1060.) Wt. 135-P. 47. 1,000. 8/20. J. T. \& S., Ltd. G. 14. Sch. 12. 
instance, while the rainfall at Willowmore is normally about 10 in., in 1919 only 5 in. had fallen. Not a green blade of grass could be seen, although near Bedford (after emerging from the Fish River valley) there is a good deal of grassveld. Even the small Karroo bushes which are adapted to extreme conditions of drought were withered everywhere, and no doubt a large number of them had died, although it is marvellous to see after a rain how so many of them, which to a casual observer look dead, sprout out again. A good deal of stock had died, yet we saw a fair amount of game, numerous herds of goats, many cattle, etc. Some progressive farmers whom we met had reserves of lucerne and had provided drinking water for their herds by means of boreholes and dams, but it seems a puzzle how the non-progressive farmers (and they are unfortunately in the majority) kept their stock alive, and how the wild bucks managed to subsist. As an example, we will take the south-west corner of the Somerset East district draining towards the Sundays River and the greater part of the Jansenville district. Here we were in what was nothing but a stony desert sprinkled over at intervals with plants, amongst which a cactaceous Euphorbia ( $E$. coerulescens, Haw.), is the most conspicuous. It occurs in clumps about $3 \mathrm{ft}$. high. It is locally known as Noors. Now this plant, which is spiny, is liked by all kinds of stock. It is slashed by the farmers, and, when half withered, is greedily eaten by the animals, or the dry herbage inside the clumps is fired and the spines are thus partly burned off. Goats and cattle will even tackle the plant as it stands, in spite of the spines. Another succulent Euphorbia $(E$. esculenta), which occurs in the same neighbourhood and which is even a better food for stock, is threatened with extermination. Our kind host on one occasion, Mr. P. Weyer, of Toekomst, pointed out to us some other valuable stock-food plants which unfortunately are getting scarce in the Karroo. Amongst them were (apart from others which are well known to S. African botanists): species of Aizoon, Aster (Diplopappus) Hermannia and Cadaba juncea. In fact, as the late Dr. MacOwan and Dr. Marloth have repeatedly pointed out, when one wants to approach the question of South African pasture plants one must get quite away from the ideas gathered from European text-books.

After my visit beautiful rains fell in the Karroo (as much as 14 in. at Graaff Reinet in two months), and the country looks in many places like a flower garden now (end of March). Especially between the fences bordering the railway line, there is in numerous places thick grass 2-3 ft. high. I had an opportunity to see this between Cradock and Naauwpoort. Owing to overstocking comparatively little grass was seen outside these fences. The dwarf Karroo bushes were supreme.

Visitors fresh from Europe may well wonder how it is that a large part of the Karroo is amongst the finest stock-countries in the world, but one of the most widely spread of the pasture plants, Pentzia virgata, has nearly the same feeding value as lucerne. Unfortunately owing to overstocking and kraaling the vegetation is rapidly deteriorating. Owing to kraaling well-defined paths are made by stock which in rain become water-courses. These 
become deeper and deeper, they widen out, and dongas are formed which carry off the rainwater rapidly, lower the water-level, etc. Attention has been frequently called to this evil, and it is hoped that before long active steps will be taken to prevent the Karroo from becoming a real desert. Some farmers have at all events tried to preserve the more or less extensive alluvial soils (which are probably the most productive in the world) from being washed away. They have built walls and formed terraces to break the force of the water-currents, and have blocked up dongas which soon get filled with silt that in many cases is excellent for crops. The terraces act at the same time as reservoirs, and on various farms we saw most marvellous results achieved by this method. For instance, on Mr. Codner's farm near Willowmore, we saw a large stack of wheat grown without irrigation in a year with a total of 5 in. of rain, on another field a good yield of green barley had been obtained; higher up there was an orchard with healthy trees of apples, pears, plums, apricots, peaches, etc., all in full bearing and quite healthy.

Five miles from Willowmore Rhenoster bosch (Elytropappus rhinocerotis) begins. This covers huge areas, especially on the northern slopes of the mountains as far as Grahamstown in the east, and is also widely spread towards the west. It is not touched by any kind of stock. Here and there progressive farmers have eradicated it at great cost. However, until we reach practically the crest of the Langeloof mountains beyond Uniondale the vegetation is to a large extent karroid. Then comes a transformation. Suddenly a few Proteaceae make their appearance, and when the crest itself is reached the Rhenoster and Karroo veld is left behind and pure south-western associations, constituting the true Cape Flora, are seen as far as the eye can reach: Proteaceae, Restiaceae, Bruniaceae, species of Cliffortia, Watsonia, Ericaceae, Orchidaceae and hosts of other plants characteristic of the southwestern Cape Flora are here met with in abundance on the southern face of the mountains, and not one (except very close to the top) can be found on the northern slopes. I have on several previous occasions passed these sharp boundaries between the karroid and south-western types, but every time I see one of them it sends a thrill through me. It is just as if we had here a large botanic garden in which the various types of plants were kept separate by artificial means, but as Marloth first pointed out, mists which do not go north of these mountain ranges and increased rainfall account for the whole difference. In fact, if we could get accurate data of the amount of " beneficial " moisture available at different seasons for plants in a particular spot (not mere rainfall statistics), we could, in Cape Colony at all events, fairly accurately predict its type of vegetation. Altitude, as Bolus first pointed out, has very little influence on the distribution of our vegetation. In fact, on the Knysna trip, we found a number of species from an altitude of over $3000 \mathrm{ft}$. to near to sea-level. Soil also plays a very secondary rôle, for instance, the Knysna forest is partly on Table Mountain sandstone, partly on Bokkeveld beds, which, having been eroded into steep slopes, retain less moisture, and consequently the forest on them is not so tall as that on the Table Mountain sandstone. 
After crossing the Langekloof (which on a previous occasion I ascertained to belong throughout its whole length to the SouthWestern Region), the real descent towards the sea is begun on the Prince Alfred Pass, and the trip from there to the Knysna is certainly the tinest in South Africa as far as my experience goes. I will not attempt to describe its beauties which culminated in reaching the Knysna forest.

There are three main groups of forest areas in the region to which the Knysna forest belongs. Henkel* calls them respectively the George, Knysna and T'Zitzikamma groups. They occur in a tract of country lying between the Great Brak River beyond George and Clarkson, near Humansdorp. They are all south of the Outeniqua -T'Zitzikamma-Kareedouw Range of mountains, the average height of which is $4000 \mathrm{ft}$., some of its peaks rising over $5000 \mathrm{ft}$. But high forest is seldom found over $2000 \mathrm{ft}$., and is consequently almost entirely restricted to the foothills of these mountains, hiding itself to a certain extent in deep ravines. The total area of high forest is approximately 112,000 aeres, and Mr. Henkel estimates that possibly 10,000 acres have been destroyed by recurring fires. Of the total amount 70,000 acres belong to the Knysna group which contains the largest patch of forest in South Africathe Knysna forest. From what has been said it follows that if we take a bird's-eye view of the zone in which these forests are located their total extent, even allowing for former extension, is hardly sufficient for one to denote this area as "the" Forest Region of South Africa and to contrast it with the South-Western Coast Region and other primary divisions. Leaving out of account the areas of the mountain ranges themselves and the Langekloof which all have typical south-western vegetation (apart from enclosures of karroid succulent vegetation on suitable rockv exposures), and which cannot be separated from the area under discussion, a rough calculation shows that the George forest patches occupy about $1 / 25$ of the area in which they occur, the Knysna group occupies $1 / 5$, and the T'Zitzikamma group about $1 / 8$ of its area. To put it in a different way: on the narrow coast plateau on which these groups are mostly found with an area of over 15,000 square miles, there used to be about 190 square miles of forest of which about 175 square miles remain, the remainder (apart from coast vegetation and patches of karroid vegetation) is typically south-western. On other grounds to which reference will be made, the separation of this part of South Africa as a Forest Region, as first introduced by Rehmann, is not advisable.

The more important trees in the high forest $\dagger$ are Ocotea bullata (4 per cent.), Podocarpus elongata, $P$. Thunbergii (11 per cent.), Cunonia capensis, Olea laurifolea (18 per cent.), Nuxia floribunda, Curtisia faginea, Platylophus trifoliatus, Apodytes dimidiata,

* Henkel, the indigenous high forest situated in the divisions of George, Knysna and Humansdorp. “S. A. Journ. of Science," Nov., 1912.

+ See Henkel, 1.c. p. 70, and Marloth, Das Kapland. The figures in brackets denote the percentage the trees represent in the Knysna forest. There are nearly 50 different kinds altogether, many of which constitute only a small fraction of the total. 
Pterocelastrus variabilis ( $7 \frac{1}{2}$ per cent.), Gonioma Kamassi ( $15 \frac{1}{2}$ per cent.), Virgilia capensis. Others do not occur so frequently. In one patch at the Knysna Faurea salignia is found. The understorey of shrub growth consists principally of 1'richocladus crinitus and numerous ferns, especially the beautiful tree-fern, Hemitelia capensis. Of the trees mentioned, Ocotea bullata has somewhat discontinuous distribution in the coast districts of South Africa, the genus Faurea does not occur again in an easterly direction until the Bashee River in the Transkei has been crossed. Virgilia capensis is south-western and stops at Van Stadens, near Port Elizabeth. Platylophus trifoliatus does not reach the Cape Peninsula in the west and also does not extend beyond Van Stadens. Thus there is a certain amount of endemism : but on the whole we recognise that these forest patches-like the forest patches further east-are distinctly outliers of the Tropical African forest ftora. In a sense they are intruders which cannot be utilised to form primary phytogeographical divisions. They are found only where the configuration of the country and other circumstances favour a greater rainfall than is found in neighbouring parts and where the plants are protected from drying winds, although all these forest trees are slightly xerophytic. It is, therefore, not likely that the South African forests, even in our narrow coast districts, had ever a wider distribution as long as climatic conditions were approximately what they are now, although the discontinuous distribution of some trees, shrubs and other forest plants seems to point in the opposite direction, and although we know that since the advent of man much forest growth has been destroyed. I have already referred to the discontinuous distribution of Ocotea bullata and Faurea. A few more examples may be quoted. Pygeum africanum occurs at Bluekrantz, near the Knysna, and is not found again in an easterly direction until we come to the neighbourhood of King Williamstown, a distance of about 250 miles. Strelitzia augusta is also found at Bluekrantz, and is not met with again when travelling eastwards until Natal is reached. Mr. J. D. Keet, district forest officer, Knysna, drew my attention in the forest to a tree-orchid which in its vegetative organs is exactly like Calanthe natalensis, not previously found west of the Pirie bush near King Williamstown. However, until this orchid has been examined when in flower, we cannot be quite sure that it is this species. Amongst animals inhabiting South African forests there are also very striking instances of discontinuous distribution known.

South Africa uses up an enormous amount of timber every year, chiefly for railway-sleepers, house-building, mine-props, wagonbuilding, furniture, etc., but it is very far from self-supporting in this respect. In former years the system of working, even of the Government forests, has been lamentable, and many parts of them have been ruined for an indefinite period. During the last 25 years or so, however, a rotation system has been introduced which allows a definite supply to be drawn from certain sections, while others have a chance to recuperate. Fortunately such a valuable tree as Ocotea bullata (Stinkwood) coppices freely, yellowwoods sow themselves freely, but all our South African valuable timber trees grow very slowly, and even do not flourish as well. 
in plantations as in their natural conditions. Much experimental work on this and other points remains, however, to be done yet, and some experiments are actually in progress at Concordia, close to the town of Knysna. In the meantime large plantations of exotic trees have been made in many places between George and Storms River (as also in other places in South Africa), and others are being formed. Before many years are past the timber from the Government plantations will exceed in value that from the natural forests, though the latter will continue to furnish valuable timber, especially for furniture, wagon-making, etc. At Concordia Pinus insignis, Pinus Pinaster, and Eucalyptus rostrata are chiefly grown. In another plantation we saw Pinus canariensis, which looked healthy and had made a good start; Cryptomeria japonica, Cork oak, Cedar, and the Camphor tree were not doing particularly well. Many others are being tried, but it is too early yet to pronounce judgment on them. Ocotea bullata, Xanthoxylon capense, Curtisia faginea, Nuxia floribunda, Toddalia lanceolata come up self-sown between pines, and it remains to be seen whether it will be worth while to retain them under these conditions. I should like to have enlarged more on the Knysna forest, on its wealth of Fungi, Bryophytes, Ferns, etc., on its climbing plants and epiphytes, but space forbids, nor can I touch on the very interesting plant formations and associations found outside the forest. The whole stretch of country from George to near Humansdorp is a botanical paradise which botanists so far have only glanced at, as the difficulties of travelling in it, even to this day, are very considerable, and large parts of even the main roads have to be negotiated very cautiously, especially in wet weather. To anybody not used to South African motor travelling it will be a novel experience to dip down into such a spot as the Bluekrantz gorge and crawl out again, or to slither into the Elands River drift. The denseness and wildness of the Knysna forest may be gauged by the fact that there is still a small herd of elephants in it; in fact, we saw their spoor near Deepwalls, close to the main road.

On our return journey we passed along the T'Zitzikamma road. As we ascended the Pass over the Kareedouw mountains, near Assegai Bush, the effects of severe drought became again apparent, and were simply appalling further on in the Uitenhage and Alexandria divisions. To give only one instance: I stopped at the corner of the Witteklip, near Van Stadens, where normally there is an abundance of flowers of plants of the SouthWestern types, yet I could get absolutely nothing, nor did I see anything in flower in the karroid scrub, which one reaches a few miles further on, when one has crossed the crest of the plateau, except the weird inflorescences of the plant which Baker calls Urginea altissima. In concluding this very brief sketch a few points of phytogeographical interest met with on the return journey may be mentioned. At Kabeljauws river, a few miles east of Humansdorp, Acacia karroo, which we had not seen since leaving the Karroo, was again met with. Here also is the western limit of Tree-Euphorbias ( $E$. tetragona). I have on another occasion pointed out that the South-Western Region goes as far 
as Port Elizabeth. This, of course, does not mean that elements characteristic of other regions are absent from it; in fact, here and there, more or less large associations which seem to be foreign to the region occur, for instance, associations of forest plants and Karroo plants, as pointed out already. From the heights east of the Gamtoos River to the beginning of the Van Stadens Gorge we travelled through typical South-Eastern grass country with scattered bush such as we find near Bathurst, south of Grahamstown. The last point I would like to refer to is this. On a previous trip I had confirmed one of Ecklon's observations-unfortunately overlooked by Bolus and others-that karroid vegetation stretches from Port Elizabeth to the mouth of the Sundays River, thus forming a broad wedge between the South-Eastern and South-Western Regions. I noticed that this wedge consists, near Coega, partly of low karroid shrublets (including Pentzia virgata). On the trip here dealt with I travelled from Uitenhage to Coega, and $I$ ascertained that there are extensive flats on this road covered with these karroid shrublets. Karroid-vegetation is also found all over the hill called the "Coega Kop," which is composed of Table Mountain sandstone, another of the numerous instances which we have of the secondary influence of geological formation on the distribution of plants in South Africa.

\section{XXXIV.-PHELLODENDRON.}

\section{T. A. Sprague.}

The genus Phellodendron (Rutaceae-Toddalieae) was described by Ruprecht in 1857 from specimens collected by Richard Maack in Amurland.* An excellent detailed generic description is given in Sargent's Trees and Shrubs, i. p. 195 (1905); the following diagnosis may, however, be useful to those who are unable to consult that work.

Trees with opposite, imparipinnate leaves. Axillary bud concealed in a little pocket between the base of the petiole and the stem. Leaflets very finely crenulate-serrulate or subentire, dotted with pellucid glands along the margins. Flowers paniculate, dioecious, pentamerous. Calyx small, 5-lobed. Petals much larger, boat-shaped, greenish-yellow, slightly imbricate. Disc none. Male flower:-Stamens 5, hypogynous, alternating with, and about twice as long as the petals; anthers sagittate, introrse. Gynophore oblong, bearing 5 rudimentary villous pistils. Female flower:-Staminodes 5, very small. Ovary subglobose, glandular-punctate, 5-locular, with a very short thick style and depressed-capitate, 5-lobed stigma. Ovules solitary, pendulous. Fruit a drupe with aromatic flesh enclosing 5 pyrenes. Endocarp cartilaginous, translucent. Seeds with a thin layer of endosperm. Embryo large; cotyledons flat.

The type-species, Phellodendron amurense, Rupr., is a tree with extremely corky bark (whence the generic name, meaning "Cork

* Bull. Acad. Pétersb. xv. p. 353 (1857). 